\title{
Different profile of interleukin-10 production in circulating $T$ cells from atopic asthmatics compared with healthy subjects
}

\author{
K Matsumoto MD, S Narita MD, T Rerecich BSc, DP Snider MD FRCPC, PM O'Byrne MB FRCPC
}

\begin{abstract}
K Matsumoto, S Narita, T Rerecich, DP Snider, PM O’Byrne. Different profile of interleukin-10 production in circulating $\mathrm{T}$ cells from atopic asthmatics compared with healthy subjects. Can Respir J 2004;11(1):33-38.
\end{abstract}

BACKGROUND: Interleukin (IL)-10 is a pleiotropic cytokine released from various cells, including T cells. Although IL-10 is suggested to inhibit allergic responses, its role in asthma remains uncertain. The purpose of the present study was to compare the profile of IL-10 in circulating $\mathrm{T}$ cells from stable atopic asthmatics, atopic nonasthmatics and healthy controls.

METHODS: Peripheral blood mononuclear cells were isolated, stained with anti-CD3 and CD4/CD8 antibodies, and then processed for intracellular IL-10 detection by flow cytometry.

RESULTS: A kinetic study in healthy controls showed that stimulation with phorbol 12-myristate 13-acetate and ionomycin significantly increased the frequencies of IL-10-producing $\mathrm{CD}^{+}, \mathrm{CD}^{+}$and $\mathrm{CD} 8^{+}$cells. Without stimulation, the frequencies of IL-10-producing $\mathrm{CD}^{+}, \mathrm{CD}^{+}$and $\mathrm{CD}^{+}$cells were significantly higher in asthmatics than in healthy controls, while a similar trend was observed in atopic nonasthmatics. Stimulation for $24 \mathrm{~h}$ significantly increased IL-10producing $\mathrm{CD}^{+}, \mathrm{CD}^{+}$and $\mathrm{CD}^{+}$cells in healthy controls and atopic nonasthmatics, but not in asthmatics.

CONCLUSIONS: The frequency of IL-10-producing $\mathrm{T}$ cells is increased in the circulation of stable atopic asthmatics compared with normal controls. The lack of enhancement in their frequency by phorbol 12-myristate 13-acetate and ionomycin in asthmatics suggests that the circulating $T$ cells of asthmatic subjects are maximally stimulated with regards to IL-10 production; alternatively, IL-10 production by $\mathrm{T}$ cells from asthmatics may be regulated differently than $\mathrm{T}$ cells from other subjects.

Key Words: Asthma; Atopy; Interleukin-10; T cells

A llergic airway inflammation is an important characteristic of atopic asthma. Proinflammatory cells, including antigenpresenting cells (APCs), eosinophils, mast cells, basophils and lymphocytes contribute to the development and persistence of the inflammation (1). There is evidence that the $\mathrm{T}$ helper (Th)2-type cytokines such as interleukin (IL)-4 or IL-5 have a role in the pathogenenesis of asthma (2). By contrast, the Th1type cytokine interferon (IFN) $-\gamma$ has an antiallergic role (3). However, recent studies showing that passive transfer of ovalbumin (OVA)-specific, Th1-skewed, $\mathrm{CD}^{+}{ }^{+} \mathrm{T}$ cells into OVAsensitized mice failed to attenuate, but rather exacerbated, airway inflammation after OVA challenge have made it difficult to understand the asthmatic inflammation based on the
Un profil différent de production d'interleukine-10 dans les lymphocytes $T$ circulants d'asthmatiques atopiques par rapport à des sujets en santé

HISTORIQUE : L'interleukine (IL)-10 est une cytokine pléiotropique libérée par diverses cellules, y compris les lymphocytes T. Bien qu'on pense que l'IL-10 inhibe les réponses allergiques, son rôle dans l'asthme demeure incertain. La présente étude visait à comparer le profil de l'IL-10 dans les lymphocytes $\mathrm{T}$ circulants chez des asthmatiques atopiques stables, des non-asthmatiques atopiques et des sujets en santé.

MÉTHODOLOGIE : Des cellules sanguines mononucléaires périphériques ont été isolées, colorées par des anticorps anti-CD3 et antiCD4 et CD8, puis traitées pour déceler l'IL-10 intracellulaire par cytométrie de flux.

RÉSULTATS : Une étude cinétique des sujets en santé a révélé qu'une stimulation par phorbol 12-myristate 13-acétate et par ionomycine accroît de manière considérable la fréquence de cellules $\mathrm{CD}^{+}, \mathrm{CD}^{+}$et $\mathrm{CD} 8^{+}$produisant de l'IL-10. Sans stimulation, les cellules $\mathrm{CD}^{+}, \mathrm{CD}^{+}$et $\mathrm{CD}^{+}{ }^{+}$produisaient beaucoup plus souvent de l'IL-10 chez les asthmatiques que chez les sujets en santé, tandis qu'une tendance similaire s'observait chez les non-asthmatiques atopiques. Une stimulation pendant 24 heures accroissait de manière considérable le nombre de cellules $\mathrm{CD}^{+}, \mathrm{CD}^{+}{ }^{+}$et $\mathrm{CD} 8^{+}$produisant de l'IL-10 chez les sujets en santé et chez les non-asthmatiques atopiques, mais pas chez les asthmatiques.

CONCLUSIONS : La fréquence de lymphocytes T produisant de l'IL-10 s'accroît dans la circulation des asthmatiques atopiques stables par rapport aux sujets en santé. L'absence d'augmentation de la fréquence par phorbol 12-myristate 13-acétate et par ionomycine chez les asthmatiques laisse supposer que les lymphocytes $\mathrm{T}$ circulants des asthmatiques sont stimulés au maximum en regard de la production d'IL-10. La production d'IL-10 par les lymphocytes $\mathrm{T}$ des asthmatiques pourrait également être régie différemment des lymphocytes $\mathrm{T}$ d'autres sujets.

simple counterbalance theory of Th1 versus Th2 (4). Thus, both Th1- and Th2-skewed responses in asthmatics may be regulated by more complex mechanisms than previously estimated. These mechanisms likely involve regulatory cytokines, including tranforming growth factor-beta and IL-10 $(5,6)$.

IL-10 is a pleiotrophic cytokine released from various types of cells, including lymphocytes, mast cells, eosinophils and monocytes/macrophages (7). While IL-10 was originally isolated as a cytokine selectively produced from Th2-cells and shown to inhibit Th1-skewed response in mice (8), it is now appreciated that not only Th2 cells, but also Th1 cells, potentially produce IL-10 in humans (9). IL-10 inhibits the production of proinflammatory cytokines from $\mathrm{T}$ cells directly and indirectly

Asthma Research Group, Firestone Institute for Respiratory Health, St Joseph's Healthcare, McMaster University, Hamilton, Ontario Correspondence: Dr Paul M O'Byrne, Firestone Institute for Respiratory Health, St Joseph's Healthcare, 50 Charlton Avenue East, Hamilton, Ontario L8N 4A6. Telephone 905-522-1155 ext 3694, fax 905-521-6125, e-mail obyrnep@mcmaster.ca 
through inhibition of the antigen-presenting functions of APCs $(10,11)$. Furthermore, IL-10 downregulates proinflammatory cytokines and chemokine production by granulocytes, and inhibits the survival of eosinophils (12). By contrast, IL-10 enhances B cell maturation into plasma cells (13). Thus, except for this proinflammatory effect on B cells, the major role of IL-10 in atopic diseases is postulated to act as a dampener of inflammation as a feedback mechanism (7).

Several studies reported that IL-10 levels in bronchoalveolar lavage (BAL) fluid and in the supernatant of cultured alveolar macrophages were lower in asthmatics than in healthy subjects $(14,15)$. However, other studies have shown that levels of IL-10 messenger ribonucleic acid (mRNA) in airway tissues and its protein in BAL fluid were higher in asthmatics $(16,17)$. A decreased level of IL-10 protein in the supernatant of peripheral blood mononuclear cells (PBMCs) from asthmatics was reported by some investigators (14), but not by others (15). Thus, the results of previous studies were inconsistent. Among those studies, the levels of IL-10 were evaluated by measuring the bulk amount of cytokine protein in the supernatant, which might not have reflected the amount of IL-10 in each type of producing cells. While alveolar macrophages are known as a major source of IL-10 $(15,17)$, T cells recruited in the lung are the other important source. Considering their orchestrating role in allergic inflammation, the production of IL-10 in T cells needs to be evaluated. T cells circulate systemically from the affected organs to the blood stream via the lymphatic system (18). This unique profile enables detection of the cytokine kinetics of $\mathrm{T}$ cells in asthmatics using peripheral blood samples. Thus, the present study investigated the numbers of IL-10-producing, circulating $T$ cells in atopic asthmatics, atopic nonasthmatics and healthy controls at the single cell level using cytokine flow cytometry (19). We hypothesized that asthmatic subjects not on regular treatment would have fewer IL-10-producing $\mathrm{T}$ cells than atopic nonasthmatics and normal subjects.

\section{PATIENTS AND METHODS}

\section{Patients}

Thirty-five subjects were studied, of whom 12 were nonatopic, healthy subjects, 10 were atopic nonasthmatics and 13 were atopic asthmatics. All patients gave signed consent before the study. The study was approved by the Ethics Committee of the McMaster University Health Sciences Centre, Hamilton, Ontario. The asthmatic group consisted of nine male and four female patients with a median age of 35 years (range 22 to 50 years). All of the patients had mild asthma as detailed by the American Thoracic Society criteria (20) and had airway hyperresponsiveness to inhaled methacholine, with a geometric mean provocation concentration of methacholine causing a fall in forced expiratory volume in $1 \mathrm{~s}$ of $20 \%$ of $3.70 \mathrm{mg} / \mathrm{mL}$ (geometric standard error of the mean $1.43 \mathrm{mg} / \mathrm{mL}$ ). No subject was treated with regular asthma therapy, and all subjects used only an inhaled beta 2 -agonist as needed, less than daily. Medication was withheld for at least $8 \mathrm{~h}$ before the investigation.

The atopic nonasthmatic group consisted of eight male and two female subjects (median age 36 years, range 28 to 43 years) who had a history of allergic rhinitis and/or conjunctivitis but who had never had asthmatic symptoms. Atopy was identified by positive skin prick test responses to one or more of the fol- lowing allergens: house dust mite, mixed grass pollens, mixed tree pollens, mixed feathers, cat fur and dog hair. They did not take any medications. No asthmatic or atopic nonasthmatic subject suffered from any comorbid condition.

The healthy control group consisted of six male and six female subjects (median age 35 years, range 27 to 49 years) who had no history of allergic diseases and negative skin tests. All subjects were nonsmokers, were not exposed to allergens and had not had exacerbations of symptoms or respiratory tract infections for at least two weeks before the investigation.

\section{Monoclonal antibodies}

Phycoerythrin (PE)-conjugated antihuman IL-10 monoclonal antibody (mAb), JES3-19F1 (rat immunoglobulin $\left[\mathrm{Ig}_{\mathrm{ga}} \mathrm{G}_{2 \mathrm{a}}\right.$ ) and PE-isotype control rat $\operatorname{IgG}_{2 \mathrm{a}}$ were purchased from PharMingen (USA). Positive staining could be inhibited by preincubation with $25 \mu \mathrm{g} / \mathrm{mL}$ recombinant human IL-10 (PharMingen, USA) or with excessive concentrations $(50 \mu \mathrm{g} / \mathrm{mL})$ of fluorescent-unlabelled antihuman IL-10 mAb. In nonpermeabilized cells, positive staining for IL-10 decreased by $31.5 \%$ of the paired sample with permeabilization, showing that approximately $70 \%$ of the signal may be the intracellular origin. Fluorescent isothiocyanate-conju-

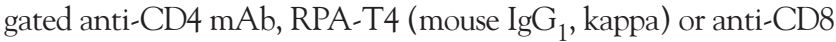
mAb, RPA-T8 (mouse $\operatorname{IgG}_{1}$, kappa) and CyChrome (PharMingen, USA)-conjugated anti-CD3 mAb, HIT3a (mouse $\mathrm{IgG}_{2 \mathrm{a}}$, kappa) were used for identifying $\mathrm{T}$ cell subsets.

\section{Cell cultures}

PBMCs were isolated by Lymphoprep (Nycomed, Norway) density gradient separation and washed with RPMI-1640 (Gibco BRL, USA). Cells were suspended in RPMI-1640 with $10 \%$ fetal calf serum (Gibco BRL, USA) and $25 \mathrm{mM}$ of Hepes (Gibco BRL) at a density of $2 \times 10^{6}$ cells $/ \mathrm{mL}$. Cells were stimulated in six-well culture plates (Becton Dickinson Labware, USA) in a volume of $5 \mathrm{~mL}$ with phorbol 12-myristate 13-acetate (PMA) (Sigma, USA) at a concentration of $10 \mathrm{ng} / \mathrm{mL}$ plus ionomycin (Sigma, USA) at a concentration of $2 \mu \mathrm{M}$ for $4 \mathrm{~h}, 8 \mathrm{~h}$ and $24 \mathrm{~h}$ at $37^{\circ} \mathrm{C}$ in $5 \%$ carbon dioxide in an incubator. Cells cultured for $4 \mathrm{~h}$ without stimulation served as a control because, in a preliminary study of unstimulated cells, a longer incubation of up to $24 \mathrm{~h}$ showed no difference in the frequency of IL-10-producing T cells. Brefeldin A (Sigma, USA) at a concentration of $10 \mu \mathrm{g} / \mathrm{mL}$ was added during the last $2 \mathrm{~h}$ of incubation to inhibit cytokine secretion. After harvest, the cell viability was assessed by the trypan blue dye (Gibco BRL, USA) method. The cells were then centrifuged at $500 \mathrm{xg}$ for $10 \mathrm{~min}$ and washed in phosphate buffered saline (PBS) with $0.2 \%$ fetal calf serum and $0.1 \%$ sodium azide (BDH Inc, Canada), referred to as washing buffer. The cells were transferred to $5 \mathrm{~mL}$ polystyrene tubes (Becton Dickinson Labware, USA) with $1 \times 10^{6}$ cells/tube and were suspended in washing buffer.

\section{Staining}

Cells were washed and suspended at a density of $1 \times 10^{6}$ cells in $100 \mu \mathrm{L}$ of PBS with $0.1 \%$ sodium azide and $5 \%$ normal mouse serum (Sigma, USA), and incubated for $10 \mathrm{~min}$ on ice; this was followed by surface staining with anti-CD3 $\mathrm{mAb}$ and anti- 
TABLE 1

Time course of interleukin-10 production (median count) in six healthy controls after stimulation with phorbol 12-myristate 13-acetate and ionomycin

\begin{tabular}{lcccc}
\hline & Control & $\begin{array}{c}\mathbf{4} \mathbf{h} \text { after } \\
\text { stimulation }\end{array}$ & $\begin{array}{c}\mathbf{8} \mathbf{~} \text { after } \\
\text { stimulation }\end{array}$ & $\begin{array}{c}\mathbf{2 4} \mathbf{~} \text { after } \\
\text { stimulation }\end{array}$ \\
\hline $\mathrm{CD}^{+}(\%)$ & $0.00(0.90)$ & $3.81(4.82)^{*}$ & $3.51(2.54)^{*}$ & $3.41(4.11)^{*}$ \\
$\mathrm{CD}^{+}(\%)$ & $0.02(0.54)$ & $3.13(7.34)^{*}$ & $2.74(4.13)^{*}$ & $5.20(7.83)^{*}$ \\
$\mathrm{CD}^{+}(\%)$ & $0.03(0.67)$ & $1.10(1.55)^{*}$ & $1.05(2.41)$ & $2.29(4.07)^{*}$
\end{tabular}

Values are presented as medians with interquartile ranges in parenthesis. ${ }^{*} P<0.05$ compared with control

CD4 mAb/anti-CD8 mAb for 20 min on ice in the dark. For intracellular cytokine staining, the cells were washed and fixed in $100 \mu \mathrm{L}$ of fixation buffer (Caltag, USA) containing 4\% paraformaldehyde for $20 \mathrm{~min}$ on ice. After a wash, cells were suspended in $100 \mathrm{~mL}$ of permeabilization buffer containing $0.1 \%$ saponin (Caltag, USA) with $5 \%$ normal rat serum (Sigma, USA) for $10 \mathrm{~min}$ at room temperature and incubated with anti-IL-10 $\mathrm{mAb}$ or isotype control $\mathrm{IgG}_{2 \mathrm{a}}$ for $30 \mathrm{~min}$ at room temperature in the dark. After a final wash, cells were suspended in PBS with $1 \%$ paraformaldehyde (BDH Inc, Canada) and kept in the dark at $4^{\circ} \mathrm{C}$ until analysis.

Flow cytometric analysis

A FACScan flow cytometer (Becton Dickinson, USA) was used for analysis. Ten thousand events were acquired in list mode, with debris excluded by the forward scatter threshold. The data were analyzed using CELLQuest software (Becton Dickinson, USA). An analysis gate was set on the lymphocyte population based on the forward and side scatter plot. Firstly, $\mathrm{CD}^{+}$-stained cells falling within the gated area were identified. The gated population was further analyzed for the identification of $\mathrm{CD}^{+}{ }^{+} \mathrm{CD} 4^{+}\left(\mathrm{CD}^{+}\right)$or $\mathrm{CD}^{+} \mathrm{CD}^{+}\left(\mathrm{CD} 8^{+}\right)$. Previous studies have shown that the stimulation with PMA and calcium ionophore downregulates surface CD4 expression on T cells, which may make it difficult to identify $\mathrm{CD}^{+} \mathrm{T}$ cells (21). Thus, the CD4+ population was also analyzed by gating on the $\mathrm{CD}^{+}{ }^{+} \mathrm{CD}^{-}$population. Cells positive for IL-10 were expressed as a percentage of each subset. The cut-off level for definition of positive cells was set so that less than $2 \%$ of isotype antibodystained cells were positive. Then, the frequency of true-positive cells was obtained by subtracting the value of isotype control from the value of sample stained with anti-IL-10 mAb.

\section{Statistical analyis}

Statistical analysis was completed using StatView J4.02 (Abacus Concepts Inc, USA). Data were expressed as medians and interquartile ranges. When multiple comparisons were made among groups, significant differences were assessed using the Kruskal-Wallis test, followed by the Mann-Whitney $\mathrm{U}$ test. Wilcoxon signed rank test was used for within-group comparisons. Values of P less than 0.05 were accepted as statistically significant.

\section{RESULTS}

Time course of IL-10 production

PBMCs from six healthy controls were examined for the relative frequencies of IL-10-producing cells after stimulation

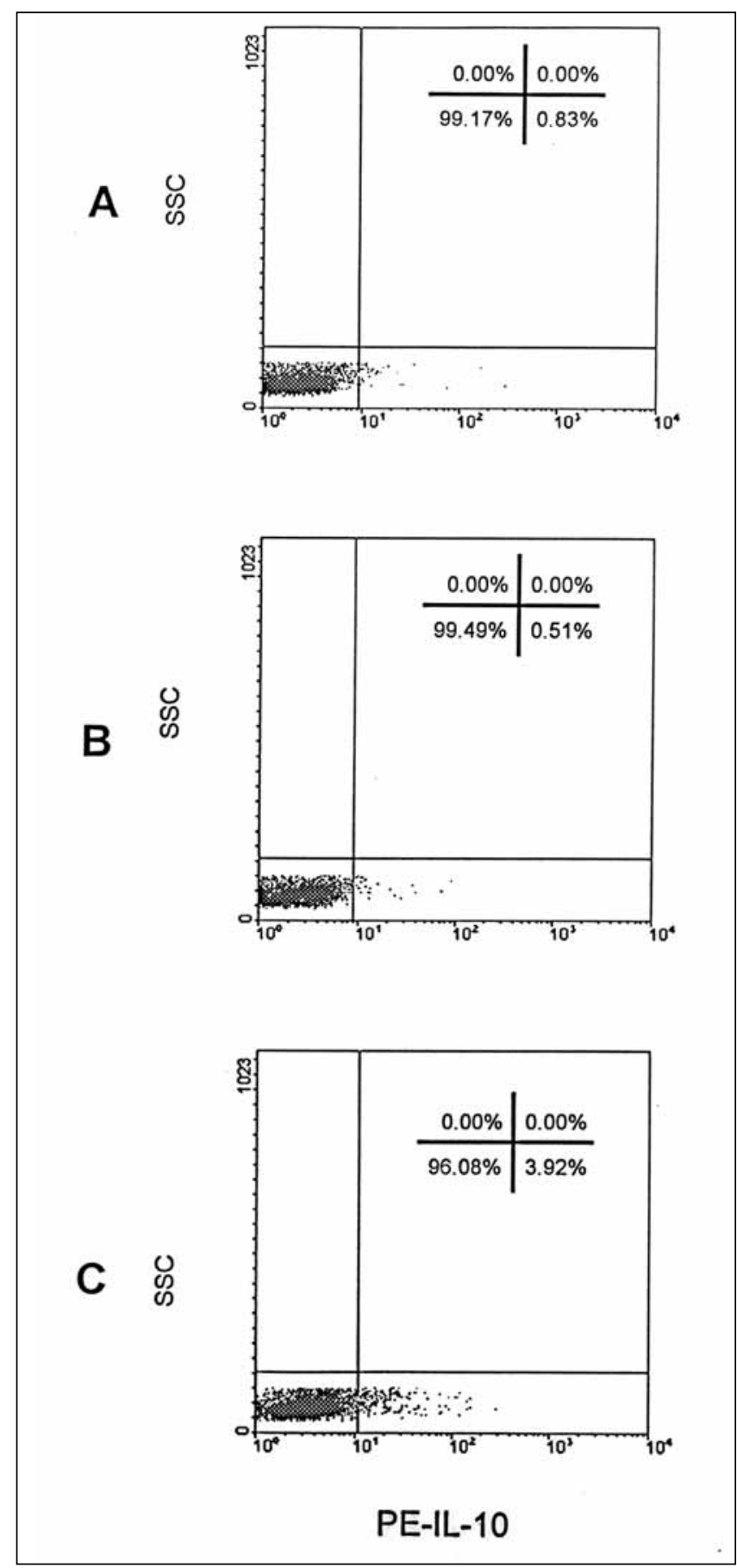

Figure 1) Typical dot plots of interleukin (IL)-10-producing $\mathrm{CD}^{+}$cells in a healthy control subject. Panel $A$ and $B$ show unstimulated samples stained with isotype control immunoglobulin $(\operatorname{Ig}) \mathrm{G}_{2 a}$ and anti-IL-10 antibody, respectively. Panel $\mathrm{C}$ shows a sample of the same subject stimulated with phorbol 12-myristate 13-acetate (PMA) and ionomycin for $24 \mathrm{~h}$, and then stained with anti-IL-10 antibody. PE-IL-10 Phycoerythrin interleukin-10; SSC Side scatter

with PMA and ionomycin (Table 1). The frequencies of IL-10-producing $\mathrm{CD}^{+}$cells after $4 \mathrm{~h}, 8 \mathrm{~h}$ and $24 \mathrm{~h}$ of stimulation were all significantly higher than that of the control samples $(\mathrm{P}<0.05)$. A typical dot plot is shown in Figure 1. Similarly, the frequencies of IL-10-producing $\mathrm{CD}^{+}{ }^{+}$cells after $4 \mathrm{~h}, 8 \mathrm{~h}$ and $24 \mathrm{~h}$ of stimulation were significantly higher than 
TABLE 2

Frequencies (median count) of interleukin (IL)-10producing cells among subject groups

\begin{tabular}{|c|c|c|c|}
\hline & $\begin{array}{l}\text { Healthy } \\
\text { controls } \\
(n=12)\end{array}$ & $\begin{array}{c}\text { Atopic } \\
\text { nonasthmatics } \\
(n=10)\end{array}$ & $\begin{array}{c}\text { Atopic } \\
\text { asthmatics } \\
(n=13)\end{array}$ \\
\hline \multicolumn{4}{|c|}{ Mononuclear cells (\%) } \\
\hline $\mathrm{CD}^{+}$ & $64.7(11.6)$ & $66.6(15.4)$ & $62.8(11.9)$ \\
\hline $\mathrm{CD}^{+}$ & $37.3(10.4)$ & $36.6(16.6)$ & $38.2(13.8)$ \\
\hline $\mathrm{CD}^{+}$ & $19.6(8.0)$ & $21.2(8.8)$ & $20.1(15.9)$ \\
\hline \multicolumn{4}{|c|}{ Baseline IL-10 (+) cells (\%) } \\
\hline $\mathrm{CD}^{+}$ & $0.00(0.90)$ & $0.40(1.54)$ & $1.61(2.37)^{\star}$ \\
\hline $\mathrm{CD}^{+}$ & $0.02(0.54)$ & $1.39(3.07)^{*}$ & $1.48(2.45)^{*}$ \\
\hline $\mathrm{CD}^{+}$ & $0.03(0.67)$ & $0.12(1.80)$ & $1.04(2.45)^{\star}$ \\
\hline \multicolumn{4}{|c|}{ Stimulated IL-10 (+) cells (\%) } \\
\hline $\mathrm{CD}^{+}$ & $3.41(4.11)^{\dagger}$ & $2.76(2.64)^{\dagger}$ & $2.10(3.54)$ \\
\hline $\mathrm{CD}^{+}$ & $5.20(7.42)^{\dagger}$ & $1.88(3.22)$ & $2.01(2.26)$ \\
\hline $\mathrm{CD}^{+}$ & $2.29(4.07)^{\dagger}$ & $2.01(2.77)$ & $1.62(2.99)$ \\
\hline
\end{tabular}

Values are presented as medians with interquartile ranges in parenthesis. ${ }^{*} P<0.05$ compared with normal controls; ${ }^{\dagger} P<0.05$ compared with baseline IL-10 (+) cells

that of the control samples $(\mathrm{P}<0.05)$. The other method for enumerating $\mathrm{CD}^{+}$cells, gated as $\mathrm{CD}^{+}{ }^{+} \mathrm{CD} 8^{-}$cells, also showed similar kinetics (data not shown). The frequencies of IL-10-producing $\mathrm{CD}^{+}$cells after $4 \mathrm{~h}$ and $24 \mathrm{~h}$ were significantly higher than that of the control samples $(\mathrm{P}<0.05)$. These results suggest that the frequencies of IL-10-producing cells reached a maximum after $24 \mathrm{~h}$ of stimulation. Therefore, we examined the frequencies of IL-10-producing cells at $4 \mathrm{~h}$ without stimulation (prestimulation) and $24 \mathrm{~h}$ with stimulation (poststimulation).

\section{Proportions of $\mathrm{CD}^{+}, \mathrm{CD}^{+}{ }^{+}$and $\mathrm{CD} 8^{+}$cells among}

\section{subject groups}

Cell viability at the beginning of incubation ranged from $97 \%$ to $100 \%$, and no significant difference was observed among subject groups. There was no difference in the proportions of $\mathrm{CD}^{+}, \mathrm{CD}^{+}$or $\mathrm{CD}^{+}$cells among subject groups (Table 2).

Frequency of IL-10-producing $\mathrm{T}$ cells at baseline

To evaluate the spontaneous production of IL-10, the frequencies of IL-10-producing cells, cultured for $4 \mathrm{~h}$ without stimulation, were compared among groups. The frequency of IL-10-producing $\mathrm{CD}^{+}$cells in asthmatics was significantly higher than in healthy controls $(\mathrm{P}=0.008)$ (Figure 2, Top). The values from atopic nonasthmatics showed an intermediate distribution between healthy controls and asthmatics. The frequencies of IL-10-producing $\mathrm{CD}^{+}$cells in both atopic nonasthmatics and asthmatics were significantly higher than in healthy controls $(\mathrm{P}=0.029$ and $\mathrm{P}=0.011$, respectively) (Figure 2, Middle). The frequency of IL-10-producing CD8 ${ }^{+}$ cells in asthmatics was also significantly higher than in healthy controls ( $\mathrm{P}=0.015$ ) (Figure 2, Bottom).

\section{The effect of stimulation on IL-10 production}

To investigate the effect of PMA and ionomycin on IL-10 production, the frequencies of IL-10-producing cells pre- and poststimulation were compared (Table 2). The stimulation

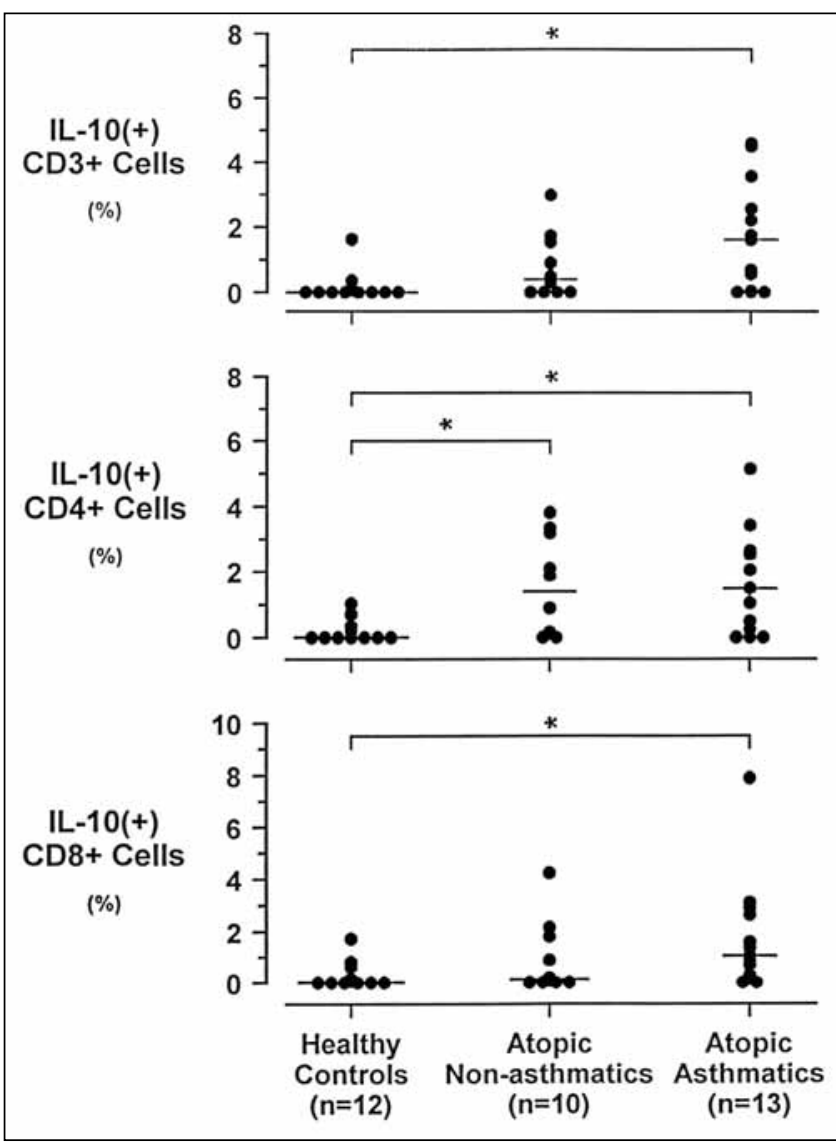

Figure 2) The frequency of interleukin (IL)-10-producing $\mathrm{CD}^{+}$cells in atopic asthmatics was significantly higher than in healthy controls. The frequencies of IL-10-producing $\mathrm{CD}^{+}{ }^{+}$cells in both atopic nonasthmatics and asthmatics were significantly higher than in healthy controls. The frequency of IL-10-producing $\mathrm{CD}^{+}$cells in asthmatics was also significantly higher than in healthy controls. ${ }^{*} \mathrm{P}<0.05$

significantly increased the frequencies of IL-10-producing $\mathrm{CD}^{+}, \mathrm{CD}^{+}$and $\mathrm{CD} 8^{+}$cells in healthy controls $(\mathrm{P}=0.003$, $\mathrm{P}=0.007$ and $\mathrm{P}=0.005$, respectively). In atopic nonasthmatics, the stimulation significantly increased the frequency of IL-10producing $\mathrm{CD}^{+}$cells $(\mathrm{P}=0.008)$, whereas for $\mathrm{CD}^{+}$and $\mathrm{CD} 8^{+}$ cells, the effect did not reach statistical significance $(\mathrm{P}=0.066$ and $\mathrm{P}=0.051$, respectively). In asthmatics, however, the stimulation did not show any effect on the frequencies of IL-10producing $\mathrm{CD}^{+}, \mathrm{CD}^{+}$and $\mathrm{CD} 8^{+}$cells. There was no difference in the frequencies of IL-10-producing $\mathrm{CD}^{+}, \mathrm{CD}^{+}$and $\mathrm{CD} 8^{+}$cells after stimulation among groups.

\section{DISCUSSION}

This study has demonstrated that the frequencies of IL-10producing $\mathrm{CD}^{+}$and $\mathrm{CD} 8^{+} \mathrm{T}$ cells were higher in atopic asthmatics than in healthy controls. In atopic nonasthmatics, the frequency of IL-10-producing $\mathrm{CD}_{4}^{+}$, but not $\mathrm{CD}^{+}, \mathrm{T}$ cells was higher than in healthy controls. Furthermore, stimulation with PMA and ionomycin increased the frequencies of IL-10producing $\mathrm{CD}^{+}$and $\mathrm{CD}^{+} \mathrm{T}$ cells in healthy controls and atopic nonasthmatics, but not in asthmatics.

The time course study using healthy control samples showed that the stimulation with PMA and ionomycin 
increased the frequencies of IL-10-producing $\mathrm{CD}^{+}$and $\mathrm{CD} 8^{+}$ $\mathrm{T}$ cells after $4 \mathrm{~h}$ of stimulation. Their frequencies reached a maximum after $24 \mathrm{~h}$ of stimulation. A previous study demonstrated that IL-10 mRNA from Th1- and Th2-like clones was first detected after $8 \mathrm{~h}$ of stimulation with anti-CD3 mAb plus phorbol acetate and reached a maximum after $24 \mathrm{~h} \mathrm{(22).} \mathrm{The}$ production of IL-10 protein, detected by ELISA, appeared after $12 \mathrm{~h}$ of stimulation and continued to increase thereafter. The earlier appearance of IL-10-producing cells in the current study seems inconsistent with the previous study. A small accumulation of IL-10 protein in the supernatant of cultured T cells at the earlier time points may not be detected by ELISA due to its limitation of sensitivity. Cytokine flow cytometry is expected to determine more detailed kinetics of IL-10 production, particularly in the early phase of activation in each subset of T cells.

At unstimulated baseline, the frequencies of IL-10producing $\mathrm{CD}^{+}$and $\mathrm{CD} 8^{+} \mathrm{T}$ cells were significantly higher in atopic asthmatics than in healthy controls. A similar difference was noted in $\mathrm{CD}^{+} \mathrm{T}$ cells between atopic nonasthmatics and healthy controls. T cells circulate systemically from the affected organs to the blood stream via the lymphatic system (18). Our findings in the peripheral blood may reflect the increased numbers of IL-10-producing $\mathrm{T}$ cells in the airways of atopic asthmatics. This speculation is supported by a report showing that IL-10 mRNA-positive T cells are increased in the airways of atopic asthmatics compared with those of healthy controls (16). Persistence of airway inflammation is frequently observed in biopsy specimens of asthmatics, even when they are symptom free (23). Based on the concept that a major role of T cell-derived IL-10 may be antiinflammatory, the increase in IL-10-producing $\mathrm{T}$ cells may be explained as chronic activation of feedback inhibitory mechanisms (7). Alternatively, the increase in $\mathrm{T}$ cell-derived IL-10 may contribute to the persistence of inflammation through its proallergic ability as an inducer of Igs - in particular, IgE from B cells (13). Indeed, IL-10 is regarded as one of the pathogenic cytokines in some autoimmune diseases, in which the overproduction of autoimmune antibodies plays a role (24).

Another interesting finding is the increased frequency of IL-10-producing $\mathrm{CD} 8^{+} \mathrm{T}$ cells in asthmatics, which was not observed in atopic nonasthmatics. While the contribution of activated/memory $\mathrm{CD} 4^{+} \mathrm{T}$ cells in asthma is widely appreciated, recent investigations have suggested that $\mathrm{CD} 8^{+} \mathrm{T}$ cells may also be involved in the development of this disease. $\mathrm{CD} 8^{+}$ $\mathrm{T}$ cells, skewed toward cytotoxic phenotype, similar to Th2phenotype in $\mathrm{CD}^{+} \mathrm{T}$ cells, acquired a capability for IL-5 production and contributed to virus-induced eosinophilia in mice

\section{REFERENCES}

1. Kirby JG, Hargreave FE, Gleich GJ, O'Byrne PM. Bronchoalveolar cell profiles of asthmatics and non-asthmatic subjects. Am Rev Respir Dis 1987;136:379-83.

2. Robinson D, Hamid Q, Ying S, et al. Prednisolone treatment in asthma is associated with modulation of bronchoalveolar lavage cell interleukin-4, interleukin-5, and interferon-cytokine gene expression. Am Rev Respir Dis 1993;148:401-6.

3. Coyle AJ, Tsuyuki S, Bertrand C, et al. Mice lacking the INF-gamma receptor have impaired ability to resolve a lung eosinophilic inflammatory response associated with a prolonged capacity of $\mathrm{T}$ cells to exhibit a Th2 cytokine profile. J Immunol 1996;156:2680-5.
(25). In asthmatics, increased numbers of IL-4 or IL-5 mRNAexpressing $\mathrm{CD}^{+} \mathrm{T}$ cells have been shown in airway biopsies, as well as an increased level of IL-4 protein in peripheral blood $\mathrm{CD}^{+} \mathrm{T}$ cells $(26,27)$.

Stimulation with PMA and ionomycin increased the frequencies of $\mathrm{IL}-10$-producing $\mathrm{CD}^{+}$and $\mathrm{CD}^{+} \mathrm{T}$ cells in healthy controls and modestly in atopic nonasthmatics, but not in asthmatics. These results were surprising because we had expected that additional stimulus would enhance T cell IL-10 production in asthmatics, in whom the frequency of IL-10producing $\mathrm{T}$ cells was increased at baseline. Although those compounds have been widely used to induce cytokine production from $\mathrm{T}$ cells in vitro, it does not seem to be the case with the induction of IL-10 in asthmatic subjects. An important caveat is that a full time course for the stimulation was not established, and time points later than $24 \mathrm{~h}$ may have given a greater response in asthmatics. However, at the $24 \mathrm{~h}$ time point, differences were noted between asthmatics and the other subjects. This raises the possibility that circulating $T$ cells of asthmatic subjects are maximally stimulated with regard to IL-10 production; alternatively, IL-10 production T cells in asthmatics may be regulated differently than $\mathrm{T}$ cells in other subjects. A further possibility is that spontaneous production of IL-10 from $\mathrm{T}$ cells in vitro suppresses the PMA- or ionomycininduced responses. Of note is a recent study that demonstrated that altering the balance between the protein kinase $\mathrm{C}$ pathway and calcium signalling redirected Th2 to Th1 and vice versa, although both signals were required for $\mathrm{T}$ cell activation (28), and stimulation for calcium signalling inhibited the production of IL-4, even in Th2 clones. Given that IL-10 has been regarded as a Th2-type cytokine and that atopic asthmatics are expected to have a Th2-skewed background, it is important to know whether a similar mechanism is involved for regulating IL-10 production.

\section{CONCLUSIONS}

The present study demonstrated that the frequency of IL-10producing $\mathrm{T}$ cells is increased in the circulation of atopic asthmatics. Additionally, the lack of enhancement in the frequency of these $\mathrm{T}$ cells by PMA and ionomycin in asthmatics raises the possibility that circulating $T$ cells of asthmatic subjects are maximally stimulated with regard to IL-10 production, or that IL-10 production by T cells in asthmatic subjects may be regulated differently than in other subjects.

ACKNOWLEDGMENTS: The authors thank Joceline Otis for technical assistance. This study was supported by the Canadian Institutes of Health Research and the Japan Heart Foundation and Bayer Yakuhin Research Grant Abroad.

4. Hansen G, Berry G, DeKruyff RH, Umetsu DT. Allergen-specific Th1 cells fail to counterbalance Th2 cell-induced airway hyperreactivity but cause severe airway inflammation. J Clin Invest 1999;103:175-83.

5. Chen Y, Kuchroo VK, Inobe J, Halfler DA, Weiner HL. Regulatory $\mathrm{T}$ cell clones induced by oral tolerance: Suppression of autoimmune encephalomyelitis. Science 1994;265:1237-40.

6. Groux H, O'Garra A, Bigler M, et al. A CD4+ T cells subset inhibits antigen-specific $\mathrm{T}$ cell responses and prevents colitis. Nature 1997;389:737-42.

7. Borish L. IL-10: Evolving concepts. J Allergy Clin Immunol 1998;101:293-7. 
8. Fiorentino DF, Bond MW, Mosmann TR. Two types of mouse helper T cell: Th2 clones secrete a factor that inhibits cytokine production by Th1 clones. J Exp Med 1989;170:2081-95.

9. Del Prete G, De Carli M, Almerigogna F, Gudizi MG, Biagiotti R, Romagnani S. Human IL-10 is produced by both type 1 helper (Th1) and Type 2 helper (Th2) T cell clones and inhibits their antigenspecific proliferation and cytokine production. J Immunol 1993;150:353-60

10. Fiorentino DF, Zlotnik A, Vieira P, et al. IL-10 acts on the antigen-presenting cells to inhibit cytokine production by Th1 cells. J Immunol 1991;146:3444-51.

11. deWaal Malefyt R, Yssel H, de Vries JE. Direct effects of IL-10 on subsets of human CD4+ T cell clones and resting T cells. Specific inhibition of IL-2 production and proliferation. J Immunol 1993; 150:4754-65.

12. Takanashi S, Nonaka R, Xing Z, O’Byrne PM, Dolovich J, Jordana M. Interleukin 10 inhibits lipopolysaccharide-induced survival and cytokine production by human peripheral blood eosinophils. J Exp Med 1994;180:711-5.

13. Rousset F, Garcia E, Defrance T, et al. Interleukin 10 is a potent growth and differentiation factor for activated human $\mathrm{B}$ lymphocytes. Proc Natl Acad Sci USA 1992;89:1890-3.

14. Borish L, Aarons A, Rumbyrt J, Cvietusa P, Negri J, Wenzel S. Interleukin-10 regulation in normal and asthmatic subjects. J Allergy Clin Immunol 1996;97:1288-96.

15. John M, Lim S, Seybold J, et al. Inhaled corticosteroids increase interleukin-10 but reduce macrophage inflammatory protein-1 $\alpha$, granulocyte-macrophage colony-stimulating factor, and interferon $\gamma$ release from alveolar macrophages in asthma. Am J Respir Crit Care Med 1998;157:256-62.

16. Robinson DS, Tsicopoulos A, Meng Q, Durham S, Kay AB, Hamid Q. Increased interleukin-10 messenger RNA expression in atopic allergy and asthma. Am J Respir Cell Mol Biol 1996;14:113-7.

17. Magnan A, van Pee D, Bongrand P, Vervloet D. Alveolar macrophage interleukin (IL)-10 and IL-12 production in atopic asthma. Allergy 1998;53:1092-5.
18. Krug N, Tschernig T, Holgate S, Pabst R. How do lymphocytes get into the asthmatic airways? Lymphocyte traffic into and within the lung in asthma. Clin Exp Allergy 1998;28:10-8.

19. Krug N, Madden J, Redington AE, et al. T-cell cytokine profile evaluated at the single cell level in BAL and blood in allergic asthma. Am J Respir Cell Mol Biol 1996;14:319-26.

20. American Thoracic Society. Definitions, epidemiology, pathophysiology, diagnosis and staging. Am J Respir Crit Care Med 1995;152:S42-83.

21. Petersen CM, Christensen EI, Andresen BS, Møller BK. Internalization, lysosomal degradation and new synthesis of surface membrane CD4 in phorbol ester-activated T-lymphocytes and U-937 cells. Exp Cell Res 1992;201:160-73.

22. Yssel H, de Waal Malefyt R, Roncarolo MG, et al. IL-10 is produced by subsets of human CD4+ T cell clones and peripheral blood T cells. J Immunol 1992;149:2378-84.

23. Laitinen LA, Laitinen A, Haahtela T. Airway mucosal inflammation even in patients with newly diagnosed asthma. Am Rev Respir Dis 1993;147:697-704.

24. Halse A-K, Tengnér P, Wahren-Herlenius M, Haga H-J, Jonsson R. Increased frequency of cells secreting interleukin-6 and interleukin-10 in peripheral blood of patients with primary Sjögren's syndrome. Scand J Immunol 1999;49:533-8.

25. Coyle AJ, Erard F, Bertrand C, Walti S, Pircher H, Le Gros G. Virus-specific CD8+ cells can switch to interleukin-5 production and induce airway eosinophilia. J Exp Med 1995;181:1229-33.

26. Ying S, Humbert M, Barkans J, Corrigan CJ, Pfister R, Menz G. Expression of IL-4 and IL-5 mRNA and protein product by CD4+ and CD8+ T cells, eosinophils, and mast cells in bronchial biopsies obtained from atopic and nonatopic (intrinsic) asthmatics. J Immunol 1997;158:3539-44.

27. Stanciu LA, Shute J, Promwong C, Holgate ST, Djukanovic R. Increased levels of IL-4 CD8 + T cells in atopic asthma. J Allergy Clin Immunol 1997;100:373-8.

28. Noble A, Truman JP, Vyas B, Vukmanovic-Stejic M, Hirst WJ, Kemeny DM. The balance of protein kinase $\mathrm{C}$ and calcium signaling directs T cell subset development. J Immunol 2000;164:1807-13. 


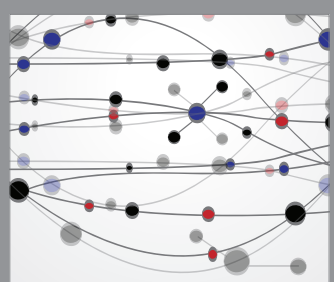

The Scientific World Journal
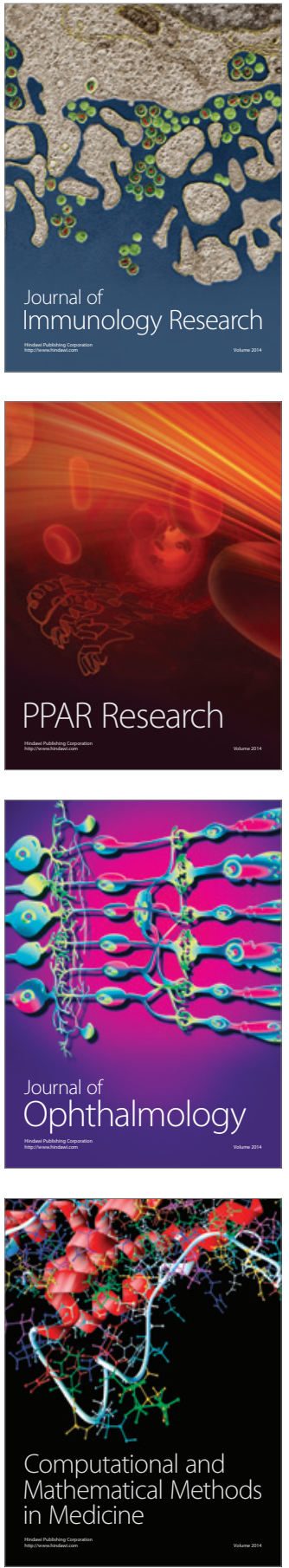

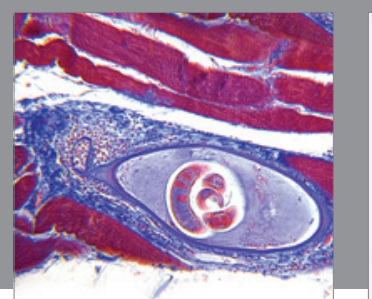

Gastroenterology Research and Practice

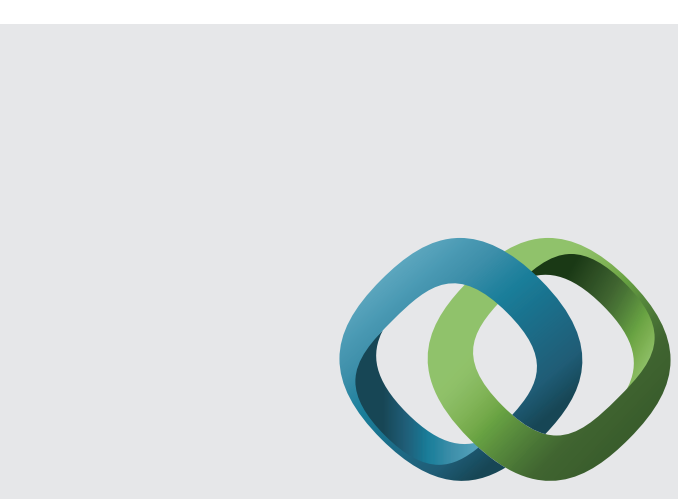

\section{Hindawi}

Submit your manuscripts at

http://www.hindawi.com
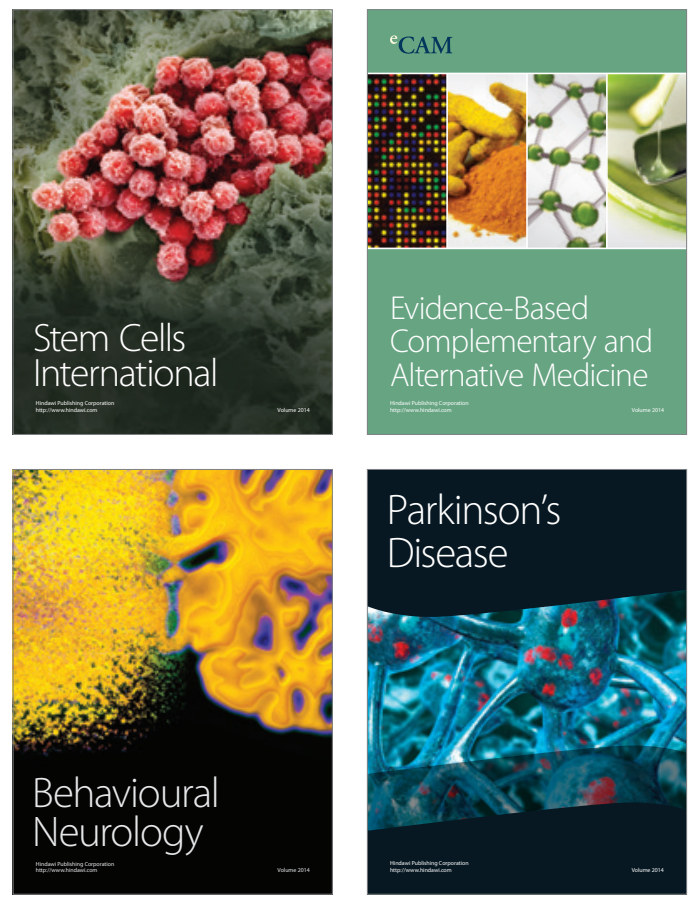
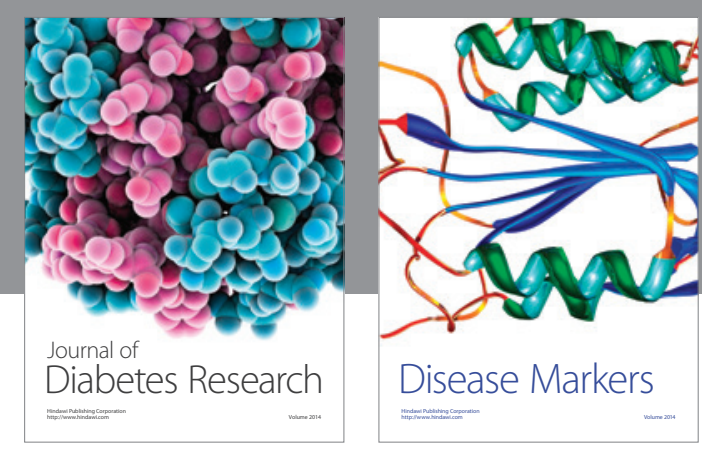

Disease Markers
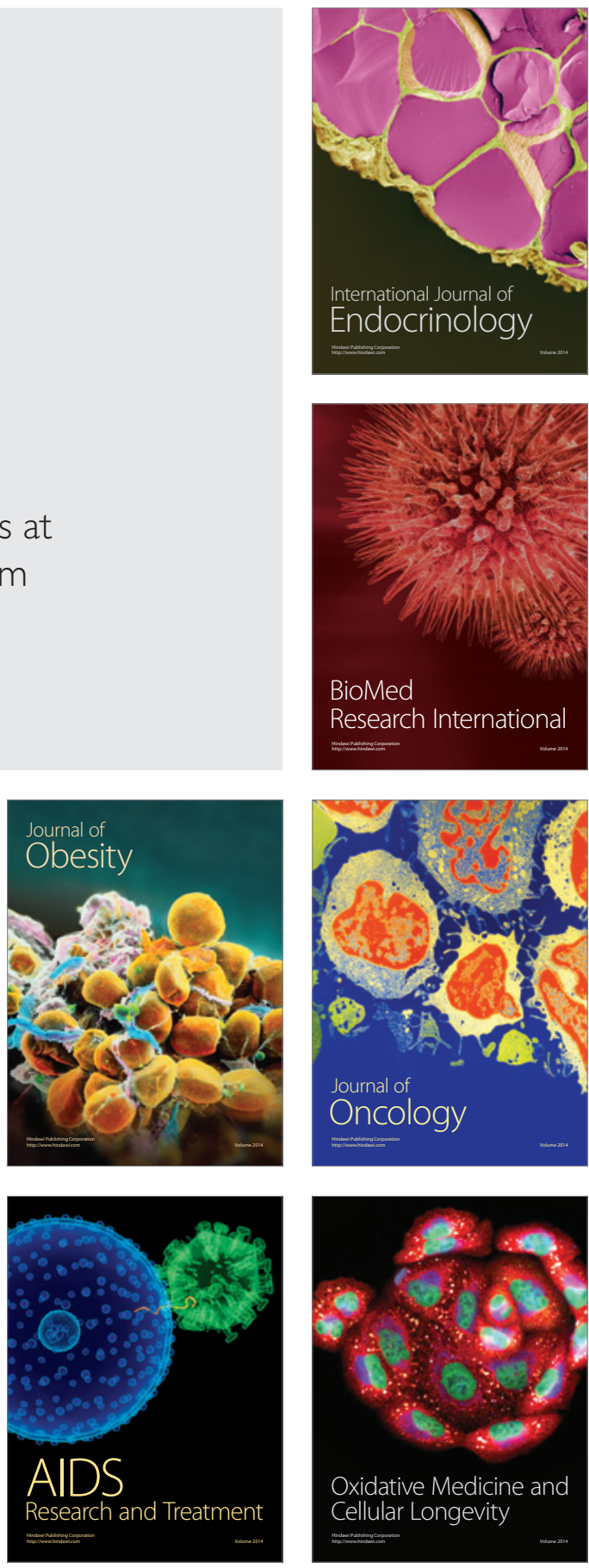